Jurnal BASTRA (Bahasa dan Sastra) : http://ojs.uho.ac.id/index.php/BASTRA

\title{
REALITAS SOSIAL DALAM KUMPULAN CERPEN TERIAKAN DALAM BUNGKAM KARYA RIZQI TURAMA
}

\author{
OLEH \\ Tanti Nur Wulandari', Sumiman Udu², dan Yunus ${ }^{3}$ \\ ${ }^{1}$ Alumni Jurusan Pend. Bahasa dan Sastra Indonesia, ${ }^{2,3}$ Dosen Jurusan Pendidikan \\ Bahasa dan Sastra Indonesia, Fakultas Keguruan dan Ilmu Pendidikan \\ Universitas Halu Oleo
}

\begin{abstract}
ABSTRAK
Penelitian ini bertujuan untuk menemukan masalah realitas sosial pada enam cerpen dalam kumpulan cerpen Teriakan dalam Bungkam karya Rizqi Turama. Metode yang digunakan dalam penelitian ini adalah metode deskriptif kualitatif. Penelitian ini termasuk jenis penelitian kepustakaan. Sumber penelitian ini adalah enam cerpen dalam kumpulan cerpen Teriakan dalam Bungkam karya Rizqi Turama yang diterbitkan oleh Histeria tahun 2017. Teknik pengumpulan data yang digunakan yaitu teknik baca catat. Data dalam penelitian di analisis mengunakan pendekatan sosiologi karya sastra. Berdasarkan hasil penelitian dalam kumpulan cerpen Teriakan dalam Bungkam pada enam cerpen yaitu cerpen Profesor bermulut runcing, Pisuh dan Makian Untuknya, Warung Bubur di Dekat Jembatan Layang, Kobal-kebul Televisi Kobel, Somat Memutuskan untuk Mati, dan Air Mata Seonggok Dasi terdapat realitas sosial pada masalah disorganisasi keluarga, masalah kejahatan, masalah kependudukan, masalah generasi muda dalam masyarakat modern, masalah delinkuensi anak-anak, dan masalah politik.
\end{abstract}

Kata Kunci: realitas, sosial, cerpen 


\section{PENDAHULUAN}

Karya sastra menceritakan berbagai masalah kehidupan manusia dalam interaksinya dengan lingkungan dan sesama, interaksinya dengan diri sendiri, serta interaksinya dengan Tuhan. Karya sastra merupakan hasil dialog, kontemplasi, dan reaksi pengarang terhadap lingkungan dan kehidupan. Walaupun berupa hasil imajinasi, khayalan, tidak benar jika karya sastra dianggap sebagai hasil kerja lamunan belaka, melainkan penghayatan perenungan secara intens, perenungan terhadap hakikat hidup dan kehidupan, perenungan yang dilakukan dengan penuh kesadaran dan tanggung jawab.

Cerpen adalah salah satu bentuk prosa baru yang menceritakan tentang sebagian kecil kehidupan pelaku utamanya yang langsung mengarah ke topik utama. Cerpen juga salah satu karya sastra yang banyak diminati oleh masyarakat karena ceritanya yang sangat menarik dan biasanya menggangkat masalah tentang masalah-masalah sosial. Masalah sosial itu berupa masalah perkawinan, percintaan, persahabatan, politik, ekonomi, agama dan lain sebagainya. Melalui cerpen dengan berbagai masalah tersebut, pengarang berusaha menyampaikan realitas sosial. Pengarang ingin menyampaikan mengenai problematika kehidupan masyarakat dalam karyanya.

Cerpen dapat dikatakan sebagai sarana yang paling efektif dan kreatif dalam menyampaikan realitas sosial. Keringkasan dan kepadatannya dalam menyuguhkan cerita tidak membuat pembaca menghabiskan waktu yang lama untuk membacanya. Cerpen akan selesai dibaca dengan waktu yang singkat. Dengan demikian, pesan yang disampaikan pengarangnya akan dengan mudah ditanggkap dan diserap pembaca. Tidak hanya itu, dengan segala permasalahannya yang universal, cerpen juga menarik untuk dikaji. Bahkan tidak pernah berhenti orang yang akan mengkajinya. Apa lagi cerpen itu dikaitkan dengan realitas sosial. Begitupun dengan penelitian ini,yang menjadi objek penelitiannya adalah realitas sosialdalam kumpulan cerpenTeriakan dalam Bungkam karya Rizqi Turama.

Buku kumpulan cerpen

Teriakan dalam Bungkam karya Rizqi Turama, di dalamnya memuat 21 cerpen dengan tema yang berbedabeda. Dari 21 cerpen yang dibuat dalam buku kumpulan cerpen ini, enam di antaranya memiliki tema yang menarik dan berkaitan dengan kehidupan sosial. Keenam cerpen tersebut yaitu Profesor Bermulut Runcing, Pisuh dan Makian Untuknya, Warung Bubur di Dekat Jembatan Layang, Kobal-Kebul Televisi Kobel, Somat Memutuskan untuk Mati, dan Air Mata Seonggok Dasi.

Dari keenam cerpen di atas yang terdapat dalam kumpulan cerpen Teriakan Dalam Bungkam karya Rizqi Turama, memberikan gambaran mengenai kepincangan-kepincangan sosial. Kepincangan sosial dalam masyarakat meliputi, masalah kemiskinan, kejahatan,masalah generasi muda dalam masyarakat modern, dan pelanggaran terhadap norma-norma masyarakat. Dengan kepincangan sosial yang ada pada keenam cerpen tersebut, menjadikan penulis tertarik untuk mengkaji 
keenam cerpen yang akan dianalisis dengan realitas sosial. Karena pada cerpen Profesor Bermulut Runcing, Pisuh dan Makian Untuknya, Warung Bubur di Dekat Jembatan Layang, Kobal-Kebul Televisi Kobel, Somat Memutuskan untuk Mati, dan Air Mata Seonggok Dasi dalam kumpulan cerpen Teriakan Dalam Bungkam karya Rizqi Turama, penulis melihat adanya masalah sosial dan relevansinya di kehidupan masyarakat pada umumnya.

\subsection{Rumusan Masalah}

Berdasarkan latar belakang yang telah diuraikan, dapat dirumuskan masalah dalam penelitian ini bagaimanakah realitas sosial di dalam enam cerpen dalam kumpulan cerpen Teriakan dalam Bungkam karya Rizqi Turama?

\subsection{Tujuan Penelitian}

Tujuan dalam penelitian ini adalah menemukan realitas sosial pada enam cerpen dalam kumpulan cerpen Teriakan dalam Bungkam karya Rizqi Turama.

\subsection{Manfaat Penelitian}

Penelitian ini diharapkan dapat memberikan manfaat sebagai berikut.

1. Penelitian ini mampu memperkaya khazanah ilmu pengetahuan terkhususnya pada analisis cerpen, realitas sosial dan pendekatan sosiologi karya sastra.

2. Sebagai salah satu rujukan bagi guru dan siswa dalam rangka meningkatkan pencapaian pembelajaran bahasa dan sastra Indonesia khusunya pada pembelajaran sastra.

3. Sebagai bahan referensi bagi peneliti lain yang akan melakukan penelitian sastra dengan permasalahan yang sejenis.

\subsection{Batasan Operasional}

1. Cerpen merupakan karya sastra hasil pengarang yang berisi gagasan, pengalaman serta imajinasi yang disampaikan oleh pengarang kepada pembaca untuk memperoleh suatu pesan.

2. Realitas sosial adalah kenyataan sosial atau peristiwa sosial yang terjadi di dalam karya sastra.

3. Sosiologi karya sastra adalah cabang penelitian sastra yang digunakan untuk melihat sastra sebagai cermin kehidupan masyarakat.

\section{KAJIAN PUSTAKA}

\subsection{Cerita Pendek}

Cerita pendek atau cerpen merupakan cerita yang menurut wujud fisiknya berbentuk pendek. Ukuran panjang pendeknya suatu cerita memang relatif. Namun, pada umumnya cerita pendek merupakan cerita yang habis dibaca sekitar sepuluh atau setengah jam. Jumlah katanya sekitar 500-5000 kata. Karena itu, cerita pendek sering diungkapkan dengan cerita yang dapat dibaca dalam sekali duduk (Kosasih, 2012: 34).

Menurut Jakob Sumardjo (dalam Sugiarto, 2015: 109) dilihat dari jumlah halaman, ada 3 jenis cerpen. Pertama, cerpen yang pendek atau short short story, cerpen jenis ini hanya terdiri atas satu halaman atau bahkan setengah halaman folio ketik. Kedua, cerpen yang terdiri atas 4 sampai 15 halaman folio yang disebut dengan midle short story. Dan yang ketiga, cerpen yang panjang biasanya terdiri atas 20 sampai 30 halaman folio disebut dengan long short story. Oleh karena itu, cerita pendek pada umumnya bertema sederhana. Jumlah tokohnya terbatas. Jalan ceritanya sederhana dan latarnya meliputi ruang 
lingkup yang terbatas. Dapat disimpulkan bahwa cerpen memiliki ciri-ciri sebagai berikut.

1. Alur lebih sederhana.

2. Tokoh yang dimunculkan hanya beberapa orang.

3. Latar yang dilukiskan hanya sesaat dan dalam lingkup yang relatif terbatas.

Sugiarto (2015: 110) menyatakan asal usul cerpen telah muncul pada abad ke-14 ketika Boccacio (Itali) menulis serangkaian bentuk prosa yang dikumpulkan dalam Decameron (dalam sebuah buku karya Aoh K. Hadimadja kumpulan karangan ini disebut dengan istilah novella). Namun, cerpen dalam bentuk yang lebih mapan seperti sekarang baru muncul pada abad ke-19 ketika beberapa majalah Amerika Serikat memerlukan tulisan berupa cerita prosa yang singkat. Cerita ini dimaksudkan agar dapat selesai dibaca dalam waktu singkat.

Berdasarkan beberapa pendapat para ahli di atas, dapat disimpulkan bahwa cerpen adalah salah satu bentuk karya sastra yang disajikan secara singkat dengan jelas dan langsung pada intinya.

\subsubsection{Unsur-unsur Cerpen}

Sebuah cerpen dibangun atas unsur-unsur yang disebut unsur-unsur cerita. Unsur-unsur tersebut dapat dibagi dua, yaitu unsur intrinsik dan unsur ekstrinsik. Unsur intrinsik adalah unsur-unsur yang secara langsung membangun sebuah karya sastra. Dengan kata lain, unsur tersebut masuk di dalam karya sastra (cerpen) itu sendiri. Unsur ekstrinsik adalah unsur yang secara tidak langsung membangun sebuah karya sastra.
Dengan kata lain unsur tersebut sesungguhnya berada di luar karya sastra (cerpen), antara lain sejarah, sosiologi, psikologi, ekonomi dan sebagainya.

Secara umum, unsur intrinsik karya sasta termasuk cerpen mencakup fakta-fakta cerita, tema, dan saran sastra. Fakta cerita meliputi tokoh dan penokohan, alur (plot), dan latar cerita yang secara faktual dapat dibayangkan keberadaannya dalam sebuah cerpen.

\subsubsection{Ciri-ciri Cerpen}

Menurut Sudarman (2008: 265269) ada beberapa ciri-ciri dari tulisan cerita pendek yaitu.

a. Kreatif

Cerita pendek ditulis atas dasar ide kreatif. Baik ide yang bertalian dengan dunia nyata maupun ide yang bersifat rekaan atau fiksi. Baik itu ide yang muncul karena direncanakan, bisa juga kebetulan. Bisa juga ide itu muncul karena desakan pihak lain, lingkungan atau dari sumber bacaan. Ide yang muncul untuk menulis cerpen, biasa juga dari pengembangan masalah atau peristiwa yang telah ada.

b. Subjektif

Cerita ditulis berdasarkan sudut pandang subjektivitas pengarangnya, artinya bahwa pengarang dari sudut penulisan bisa kita tulis dalam bentuk 'aku', ia, dia dan lain-lain. Maksudnya unsur "aku" dalam sebuah cerpen memungkinkan seseorang pengarang memasukan emosi dan pikirannya dalam karya tulisnya. Subjektivitas cerpen tampak pula dari kedekatannya dengan unsur sastra. Seorang penulis, ketika menulis cerpen bisa mencampurkan unsur-unsur fakta dan fiksi, atau fakta saja atau fiksi saja.

\begin{tabular}{ll}
\multicolumn{3}{c}{ Subjektivitas dalam } & cerpen, \\
dapat pula diartikan sebagai & sanan \\
pengungkapan perasaan dan & pikiran
\end{tabular}


sesuai dengan nila-nilai atau konsep seseorang. Apa pun yang diungkapkan merupakan subjektivitas seseorang yang dipengaruhi oleh insting, implus, emosi, pikiran, budaya serta lingkungan interaksi yang kemudian melahirkan pola tingkah subjektivitas yang berbeda.

c. Informatif

Ciri lain dari cerita pendek yaitu dapat memberikan informasi lebih lengkap kepada masyarakat. Terutama mengenai suatu situasi peristiwa atau aspek kehidupan. Tulisan dalam cerpen biasanya lebih mendalam sehingga mampu memberikan gambaran lebih detail tentang peristiwa atau suatu permasalahan. Dalam mengungkapkan kondisi sosial, cerpen biasanya lebih menggugah dan memunculkan empati dan rasa haru pembaca. Informasi yang disampaikan melalui cerpen yang ditekankan adalah dapat menyentuh rasa kemanusian (human touch) pembacanya, sehingga pembaca bisa terharu, terpengaruh dan terbujuk melakukan sesuatu.

d. Mendidik

Tulisan cerpen menyajikan tentang apa yang diketahui pengarangnya, dapat mendorong perkembangan intelektual pembacanya. Sehingga pembaca memiliki pengetahuan baru, cara pandang baru, bersikap baru sesuai dengan ilmu yang ditawarkan pengarangnya. Misalnya tentang bagaimana akibat orang yang rakus, biasanya pengarang akan memberikan sanksi moral bagi pelakunya, seperti datangnya bencana, duka lara, kehinaan, dan keadaan buruk lainnya. Sebaliknya, bagi tokoh yang berwatak baik seperti sabar, dermawan, saleh, biasanya pengarang memberikan balasan dengan akhir cerita yang menyenangkan.

e. Menghibur
Tulisan dalam bentuk cerpen termasuk karya sastra yang bersifat menghibur. Pembaca dalam memahaminya cenderung menggunakan emosi dari pada pikirannya. Untuk menyentuh emosi pembaca, gaya penulisan cerpen pun ditulis dengan gaya menghibur. Sifat menghibur ini penting, karena sekali waktu seseorang memang membutuhkan hiburan yang dapat menimbulkan rasa senang serta mampu mengembangkan selera estetiknya.

f. Ditulis berdasarkan fakta dan bisa juga berdasarkan imajinasi

Cerpen bisa berdasarkan fakta, peristiwa nyata, bisa juga mengandalkan imajinasi belaka. Bisa juga memadukan keduanya, baik berdasarkan fakta maupun imajinasi. Fakta peristiwa bisa diperoleh dari masalah-maslah kehidupan sehari-hari, seperti dalam bidang sosial, pendidikan, ekonomi, politik, budaya, dan lain sebagainya.

\subsubsection{Perbedaan Cerpen dengan Karya Sastra yang Lain}

Daya tarik sebuah cerpen bisa disebabkan pada berbagai hal seperti, temanya yang langka atau sedang teralami, alurnya yang mendebarkan, cara penyelesaian cerita yang penuh kejutan, tokoh-tokohnya yang penuh simpatik dan heroik, latarnya penuh pesona dan rangkaian kata yang memikat.

Kelebihan cerpen dibandingkan karya sastra lain seperti novel, cerpen memiliki kelebihan yang khas yaitu kemampuannya mengemukakan secara lebih banyak apa yang terkandung dari sekedar apa yang diceritakan. Dari segi panjang cerita novel (jauh) lebih panjang dari cerpen. Oleh karena itu, novel dapat mengemukakan sesuatu 
secara bebas, menyajikan sesuatu secara lebih banyak, lebih rinci, lebih detail, dan lebih banyak melibatkan berbagai masalah yang lebih kompleks hal itu mencakup unsur cerita yang membangun novel itu. namun justru hal inilah yang menyebabkan cerpen lebih padu, lebih memenuhi tuntutuan ke-unity-an daripada novel karena bentuknya yang pendek, cerpen menuntut penceritaan yang serba ringkas, tidak sampai pada detail-detail khusus yang "kurang penting" yang lebih bersifat memperpanjang cerita (Nurgiyantoro, 2010:11).

\subsection{Realitas Sosial dalam Karya Sastra}

Realitas sosial mengandung arti kenyataan-kenyataan sosial di sekitar lingkungan masyarakat tertentu. Masyarakat terbentuk karena manusia menggunakan pikiran, perasan dan keinginannya dalam memberikan reaksi terhadap lingkungannya. Hal ini terjadi karena manusia mempunyai keinginan pokok yaitu, keinginan untuk menjadi satu dengan lingkungan alamnya. Menurut Sztompka (dalam Mei, 2017:4) realitas sosial adalah realitas hubungan antara individual, segala hal yang ada di antara manusia, jaringan dan ikatan, ketergantungan, pertukaran, dan kesetiakawanan. Dengan kata lain realitas sosial adalah jaringan sosial khusus atau jaringan sosial yang mengikat orang menjadi suatu kehidupan bersama.

Realitas sosial dalam karya sastra menunjukkan sebuah peristiwa yang terjadi di dunia nyata yang diimajinasikan kembali oleh pengarang dalam sebuah karya sastra. Dalam karya sastra, banyak terjadi interaksi antar individu yang membentuk suatu peristiwa. Peristiwa antar individu tersebut menimbulkan gejala sosial dalam karya sastra. gejala tersebut merupakan hasil dari rekaan pengarang yang dihasilkan dari kenyataan tersebut yang menunjukkan realitas dalam karya sastra.

\subsection{Jenis Masalah Sosial sebagai Realitas Sosial dalam Cerpen}

Realitas sosial dalam karya sastra memberi gambaran mengenai masalah-masalah sosial yang terjadi dalam tata kehidupan masyarakat. Menurut Soekanto (1993: 406-434) kepincangan-kepincangan yang dianggap sebagai masalah sosial oleh masyarakat tergantung dari sistem nilai sosial masyarakat tersebut. Akan tetapi ada beberapa persoalan yang dihadapi oleh masyarakat pada umumnya sama yaitu.

a. Kemiskinan.

b. Kejahatan.

c. Disorganisasi Keluarga.

d. Masalah Generasi Muda dalam Masyarakat Modern.

e. Pelanggaran Terhadap NormaNorma Masyarakat.

f. Masalah Kependudukan.

\subsection{Pendekatan dalam Analisis}

\section{Cerpen}

\subsubsection{Sosiologi Sastra}

Menutur Laurenson dan Swingewood (dalam Endraswara, 2011: 78) kendati sosiologi dan sastra mempunyai perbedaan tertentu namun sebenarnya dapat memberikan penjelasan terhadap makna teks sastra. Hal ini dapat dipahami, karena sosiologi objek studinya tentang manusia dan sastra pun demikian. Sastra adalah ekspresi kehidupan manusia yang tak lepas dari akar masyarakat. Dengan demikian, meskipun sosiologi dan sastra adalah kedua hal yang berbeda namun dapat saling melengkapi. Dalam hal ini, sastra merupakan sebuah refleksi 
lingkungan sosial budaya yang membentuknya atau merupakan penjelasan suatu sejarah dialektik yang dikembangkan dalam karya sastra.

Sosiologi sastra dapat meneliti sastra sekurang-kurangnya melalui tiga perspekti. Pertama, perspektif teks sastra, artinya peneliti menganalisis sebagai sebuah refleksi kehidupan masyarakat dan sebaliknya. Teks biasanya dipotong-potong, diklasifikasikan, dijelaskan makna sosiologisnya. Kedua, perspektif biografis, yaitu peneliti menganalisis pengarang. Perspektif ini akan berhubungan dengan life history seorang pengarang dan latar belakang sosialnya. Memang analisis ini akan terbentur pada kendala jika pengarang telah meninggal dunia, sehingga tidak bisa tanyai. Karena itu, sebagai sebuah perspektif tentu diperuntukkan bagi pengarang yang masih hidup dan mudah dijangkau. Ketiga, perspektif reseptif, yaitu peneliti menganalisis penerimaan masyarakat terhadap teks sastra (Endraswara, 2011: 80).

\subsubsection{Pendekatan Sosiologi Karya Sastra}

Wellek dan Werren (2014: 100) mengemukakan setidaknya ada tiga jenis pendekatan yang berbeda dalam sosiologi sastra. Pertama, sosiologi pengarang, profesi pengarang, dan institusi pengarang. Masalah yang beraitan disini adalah dasar ekonomi produksi sastra, latar belakang sosial, status pengarang, dan ideologi pengarang yang terlihat dari berbagai kegiatan pengarang di luar karya sastra. Kedua, sosiologi karya sastra adalah isi karya sastra, tujuan, serta hal-hal lain yang tersirat dalam karya sastra itu sendiri dan yang berkaitan dengan masalah sosial. Dan ketiga, sosiologi pembaca adalah permasalahan pembaca dan dampak sosial karya sastra.

\section{METODE PENELITIAN}

\subsection{Metode dan Jenis Penelitian}

\subsubsection{Metode Penelitian}

Metode yang digunakan dalam penelitian ini adalah metode deskriptif kualitatif. Metode deskriptif kualitaif digunakan untuk mendeskripsikan dan menginterpretasi data-data tertulis yang berupa satuan cerita yang terwujud dalam monolog maupun dialog tokoh yang terdapat pada enam cerpen dalam kumpulan cerpen Teriakan dalam Bungkam.

\subsubsection{Jenis Penelitian}

Jenis penelitian yang digunakan dalam penelitian ini adalah penelitian kepustakaan. Penelitian kepustakaan adalah penelitian yang dilakukan melalui sejumlah bahan bacaan yang berkaitan dengan masalah sosial masyarakat melalui referensi yang mendukung penelitian.

\subsection{Data dan Sumber Data}

\subsubsection{Data}

Data yang digunakan dalam penelitian ini adalah realitas sosial yang terdapat pada enam cerpen dalam kumpulan cerpen Teriakan dalam Bungkam karya Rizqi Turama.

\subsubsection{Sumber Data}

Sumber data utama dalam penelitian ini adalah kumpulan cerpen Teriakan dalam Bungkam karya Rizqi Turama, terkhusus pada enam cerpen yang berjudul Profesor Bermulut Runcing, Pisuh dan Makian Untuknya, Warung Bubur di Dekat Jembatan Layang, Kobal-Kebul Televisi Kobel, Somat Memutuskan untuk Mati, dan Air Mata Seonggok Dasi. kumpulan 
cerpen Teriakan dalam Bungkam diterbitkan oleh Histeria tahun 2017 dengan jumlah 220 halaman.

\subsection{Teknik Pengumpulan Data}

Teknik pengumpulan data yang digunakan dalam penelitian adalah teknik baca catat.

\subsection{Teknik Analisis Data}

Data dalam penelitian ini dianalisis berdasarkan bentuk masalah realitas sosial dengan menggunakan pendekatan sosiologi karya sastra, untuk mengetahui relevansi keadaan yang digambarkan pada enam cerpen dalam kumpulan cerpen Teriakan dalam Bungkam dengan keadaan masyarakat.

\section{HASIL DAN PEMBAHASAN}

\subsubsection{Realitas Sosial dalam Cerpen} Profesor Bermulut Runcing

\subsubsection{Realitas Sosial Tentang} Masalah Disorganisasi Keluarga

Dalam cerpen Profesor bermulut runcing terdapat realitas sosial pada masalah disorganisasi keluarga. Masalah disorganisasi keluarga merupakan masalah perpecahan yang dialami sebuah keluarga. Dalam cerpen ini masalah disoganisasi keluarga berawal dari perselinghukan suami yang dilakukan dibelakang sang istri. Yang pada akhirnya membuat sang istri merubah kepribadianya semenjak peristiwa tersebut. Sang istri yang bergelar profesor setiap mengeluarkan kataa-kata dari mulutnya membuat sakit hati orang yang mendengarnya.

Jauh hari sebelum profesor kita menjadi profesor dan baru saja lulus sebagai doktor, tujuh tahun lalu tepatnya, ia mendapati bahwa suaminya berselingkuh. Suaminya ingin berkelit, tapi ketika melihat doktor itu memegang telepon genggam yang isinya adalah percakapan mesrum (mesra dan mesum) dengan orang lain, sang suami membatalkan niat tersebut. Dengan geraham yang bergemelutuk, napas tersengal, dan air yang mengambang di pelupuk mata, doktor yang belum jadi profesor itu berkata, "Aku ingin bertemu dengan selingkuhanmu." (Profesor Bermulut Runcing: 22-23)

Dari kutipan di atas menujukkan bahwa seorang suami berselingkuh di belakang istrinya dan ketahuan oleh sang istri. Memberikan gambaran kurangnya kepedulian keluarga terutama suami yang tidak mampu dalam menegakkan nilai-nilai keluarga maupun menegakkan harkat dan martabat keluarga. Suami yang berselingkuh dari istrinya tentu telah gagal menjaga keharmonisan ataupun harkat dan matrabat keluarga. Dalam ketidakberdayaan seorang perempuan saat mengetahui suaminya berselingkuh dengan wanita lain melalui telepon genggam dan memutuskan untuk bertemu dengan wanita itu, sang suami berniat untuk mengelak dari perbuatannya, tetapi suami sadar bahwa ia tidak akan bisa mengelak dari istrinya. Hal ini menunjukkan perselingkuhan bisa terjadi di mana saja dengan mengunakan semua jenis media.

\subsubsection{Realitas Sosial dalam Cerpen Pisuh dan Makian Untuknya}

\subsubsection{Realitas Sosial Tentang Masalah Kejahatan}

Berawal dari seorang polantas bernama Pisuh yang berbeda dari polantas yang lainnya. Ketika ada pelangar lalu lintas ia tidak menerima uang damai yang diberikan kepadanya, hal inilah yang membuat Pisuh tidak disukai oleh rekan kerjanya dan 
mengakibatkan rekan kerjanya menebar ujaran kebencian terhadap Pisuh.

Memang akibatnya ia jadi dicibir oleh rekan-rekan seprofesi. Dibilang sok suci, bodoh, tidak pandai membaca peluang, menyia-nyiakan kesempatan, dan sebagainya. Banyak ejekan lain yang tertuju untuk Pisuh karena sikapnya yang tidak umum. Sebagian dari ejekan itu dinyatakan terangterangan di depan, walaupun jelas lebih banyak lagi yang nyinyir di belakang. Ditambah-tambahi dengan bumbu-bumbu penyedap gosip. Sehingga langsung atau tidak langsung, mereka membuat Pisuh sulit mendapatkan teman. Pisuh juga tidak mengerti mengapa atasannya begitu dingin. Sikap sang atasan yang menganaktirikan ia. Begitu yang dirasakan oleh Pisuh. Mungkin memang orang-orang sulit menerima sikap yang berbeda, meskipun kadang justru yang berbeda itulah yang benar (Pisuh dan Makian Untuknya: 68).

Kutipan di atas menunjukkan bahwa rekan seprofesi Pisuh menebar ujaran kebencian kepadanya karena sikapnya yang berbeda dengan rekanrekannya. Pisuh di nilai lain dengan rekan kerjanya yang menyia-nyiakan kesempatan tidak menerima uang damai atau pun meminta uang damai kepada para pelanggar lalu lintas. Sikap atasan pisuh yang berbeda terhadap dirinya tidak seperti sikap yang diberikan atasannya kepada rekan-rekan Pisuh. Berada di lingkungan yang tidak satu pemahaman atau memiliki perbedaan memang sulit untuk diterima walaupun justru yang berbeda itulah yang benar. Bukan hanya rekan seprofesinya yang mencibir kelakuan Pisuh, bahkan para pelanggar atau pun tetangganya akan mencibir sikap Pisuh yang berbeda.

\subsubsection{Realitas Sosial Tentang Masalah Kemiskinan}

Pisuh yang mengalami masalah kemiskinan terpaksa harus merubah prisip yang dipegangnya selama tujuh tahun masa baktinya, ia mulai meminta uang damai dari pelanggar lalu lintas. Ia harus memenuhi kebutuhan keluarganya disaat bersamaan, dimana ia membutuhkan biaya berobat untuk sang ibu dan biaya persalinan untuk sang istri.

Dan berapa biaya yang disebutkan oleh dokter itu? Pisuh tidak mengingatnya dengan jelas. Yang pasti nolnya banyak. Belum lagi berapa biaya untuk setiap cuci darah? Dari mana ia mendapatkan uang sebanyak itu? Tapi, cuma dia yang bisa diandalkan keluarga. Pikiran Pisuh mulai kacau. Apalagi ia juga harus mempersiapkan kelahiran anak pertamanya. Anak yang selama ini ia nanti-nantikan kedatanggannya. Masalahnya melahirkan juga akan membutuhkan biaya yang tidak sedikit. Lalu dari mana ia bisa dapat semua uang itu? untuk ibu dan istrinya sekaligus (Pisuh dan Makian Untuknya: 70).

Kutipan di atas menunjukkan bahwa Pisuh mengalami kesulitan di mana semua kebutuhan harus ia tanggung, saat semua bergantung pada Pisuh terutama ibu dan istrinya yang memerlukan perhatian khusus. Ibunya yang sakit harus melakukan cangkok ginjal serta melakukan cuci darah selama proses cangkok ginjal dinyatakan berhasil dan disaat bersamaan Pisuh harus mempersiapkan kelahiran anak pertamanya yang selama ini ia nantikan-nantikan. Semua itu memerlukan biaya tidak sedikit. Pisuh memerlukan bantuan orang- 
orang disekitarnya untuk mengurangi masalah yang dialaminya. Namun, tidak mudah bagi Pisuh menemukan orang yang mau membantunya.

\subsubsection{Realitas Sosial dalam Cerpen Warung Bubur di Dekat Jembatan Layang}

4.1.3.1 Realitas Sosial Tentang Masalah Kependudukan

Realitas sosial masalah kependudukan, pembangunan jembatan yang dilakukan untuk mengatasi kemacetan akibat kepadatan penduduk. Pembangunan ini tidak memebrikan solusi atas kemacetan yang terjadi justru kemacetan semakin parah dan pembangunan jembatan membawa dampak negatif bagi para pedagang kaki lima disekitarnya salah satunya adalah warung bubur.

Proses pembangunan jembatan layang itu memakan waktu dua tahun. Selama dua tahun itu masyarakat Palembang disiksa dengan kemacetan luar biasa karena ruas jalan yang digunakan hanya setengah dari biasanya. Sebuah ironi, solusi atas sebuah masalah adalah dengan membuat sumber masalah baru (Warung Bubur di Dekat Jembatan Layang: 89).

Kutipan di atas menggambarkan pembangunan jembatan yang seharusnya memberikan solusi atas sebuah masalah tetapi justru menimbulkan masalah. Kemacetan yang harusnya diatasi, justru dengan pembangunan jembatan membuat kemacetan semakin parah. Dan bahkan setelah pembangunan jembatan selesai kemacetan masih sering terjadi. Masyakarat dengan ekonomi golongan menengah ke bawah tidak ketinggalan terkena dampak dari pembembangunan jembatan.

\subsubsection{Realitas Sosial Tentang Masalah Generasi Muda dalam Masyarakat Modern}

Sikap apatis yang ditunjukan oleh tokoh aku ketika melihat perkelahian disekitarnya terjadi. Tokoh aku tidak berusaha melerai perkelahian itu, seharusnya ia memisahkan kedua belah pihak yang berkelahi.

Maka sejak hari itu, aku kembali menjadi orang tak bisa disebut pelanggan tetap, tapi suka makan di sana. Bedanya, setiap kali aku kesana, warung itu tak pernah ramai. Paling banyak hanya empat orang termasuk aku sendiri. Hanya ada suatu kali saat aku tengah makan, tiba-tiba warung itu mejadi ramai. Sayangnya bukan karena pelanggan, melainkan karena ada orang yang berkelahi di dekat situ (Warung Bubur di Dekat Jembatan Layang: 92).

Kutipan di atas menggambarkan tokoh aku yang sedang makan disebuah warung melihat suatu kejadian yaitu ada orang yang terlibat perkelahian di dekat warung tempat ia makan. Pada hakikatnya ketika ada perkelahian yang disaksikan seharusnya mengambil tindakan untuk memisahkan orang yang sedang berkelahi. Tetapi, tidak dengan tokoh aku yang bersikap apatis.

\subsubsection{Realitas Sosial dalam Cerpen Kobal-Kebul Televisi Kobel}

\subsubsection{Realitas Sosial Tentang} Masalah Delinkuensi Anakanak

Dalam cerpen kobal-kebul televisi Kobel terdapat realitas sosial masalah delinkuensi anak-anak. Masalah ini mengambarkan bagaimana bobroknya tontonan televisi saat ini yang hanya memikirkan keuntuntang tanpa ada 
unsur pendidikannya. Anak-anak yang harunya menorehkan prestasi justru meniru adegan tidak senonoh yang di tampilkan oleh acara televisi.

Demi mendengar itu Kobel terbelalak matanya. Napas pun sempat terhenti untuk beberepa saat. Sangat mungkin ia berpikir bahwa yang didengarnya adalah berita buruk dan tak ada yang lebih buruk lagi dari itu. Sampai akhirnya anak gadis itu, tetap dengan wajah menggemaskan, berkata, "Kalau ciuman yang cuma nempel kayak itu, aku juga sudah pernah.” (Kobal-Kebul Televisis Kobel: 99).

Kutipan di atas menggambarkan bahwa kondisi generasi muda saat ini, memerlukan perhatian khusus. Terlihat si anak tidak malu mengaku pada Kobel bahwa dirinya telah melakukan hal tak senonoh, ia menganggap bahwa ciuman itu adalah hal biasa. Tentu hal ini memerlukan perhatian khusus yang harus dilakukan Kobel dan istrinya.

\subsubsection{Realitas Sosial dalam Cerpen Somat Memutuskan untuk Mati}

\subsubsection{Realitas Sosial dalam Cerpen} Somat Memutuskan untuk Mati

Berbeda dalam menentukan hak pilih saat pemilu adalah hal wajar. Tetapi tidak pada keluarga Somat, ibu somat yang memilih sang mantan jendral dan istri Somat yang memilih mantan tukang kayu justru bertikai. Keduanya membela habis-habis jagoan yang dipilih. Somat merasa kecewa dengan sikap ibu dan istrinya, calon yang mereka dukung secara berlebihan, ketika terpilih nanti akan melupakan janji-janji politiknya.

Jangan kalian berpikir bahwa ada perselingkuhan atau cerita-cerita libidinal sejenis yang terjadi sehingga Somat tak betah lagi tinggal di rumah. Bukan itu sebabnya. Tiada hari terlewati tanpa perang dingin antara ibu dan istrinya. Gara-gara pemilu celaka dua tahun lalu, rumahnya bagaikan terbuat dari es. Dingin dan beku. Namun, membuat tangan terasa panas ketika menggenggamnya. Ya. Ini karena pertempuran perebutan suara antara mantan jendral dan mantan tukang kayu (Somat Memutuskan untuk Mati: 150).

Kutipan di atas menunjukkan dampak negatif dari politik yang dirasakan oleh Somat. Somat tidak betah lagi tinggal di rumah. Disebakan perang dingin yang terjadi antara ibu dan istrinya. Ibu dan istrinya yang memiliki perbedaan pilihan pada pemilihan umum dua tahun silam yang mengakibatkan perang dingin ini terjadi.

\subsubsection{Realitas Sosial Tentang Masalah Disorganisasi Keluarga}

Ketidakmampuan Somat untuk melerai kedua orang yang dikasihinya ketika bertikai akibat berbeda dalam menentukan hak pilih dalam pemilu, membuat kehidupan rumah tangga Somat menjadi tidak harmonis. Pertikaian yang terjadi anatara ibu dan istri Somat dan tidak kunjung usai membuat Somat putus asa dan pada akhirnya Somat memutuskan untuk mati.

Dalam ketidakberesan kerja otaknya akibat tekanan bertubi-tubi, Somat memutuskan untuk mengakhiri hidup. Disiapkannya tali dan diikat ke langitlangit rumah. Kakinya sudah menjijit dan lehernya telah dikalungkan ke tali laknat tersebut saat tiba-tiba istri dan ibunya mendobrak pintu kamar (Somat Memutuskan untuk Mati: 156).

Kutipan di atas menunjukkan keputusasaan yang dipilih oleh Somat untuk menghadapi masalah yang terjadi antara ibu dan istrinya. Rumah tangga Somat yang penuh dengan 
tekanan akibat pertikaian ibu dan istrnya. Kedamaian di dalam rumah Somat sudah tidak ada lagi. Somat tidak tahan lagi dengan apa yang terjadi pada ibu dan istinya. Keduanya terus memberikan Somat pertanyaan yang sama dan Somat tidak bisa menjawab pertanyaan itu. Pada akhirnya Somat memutuskan untuk bunuh diri.

\subsubsection{Realitas Sosial dalam Cerpen Air Mata Seonggok Dasi}

Dalam cerpen air mata seonggok dasi terdapat realitas sosial masalah kejahatan. Kejahatan yang terjadi di dalam cerpen ini adalah pembunuhan yang dilakukan oleh sang tuan teradapa selingkuhannya. Ia berselingkuh di belakang istrinya. Saat sang selingkuhan mengandung anak dari perbuatannya, sang tuan tidak mau bertanggung jawabjustru memilik untuk membunuh selingkuhan dengan menggunakan sebuah dasi.

Senja tadi kedua manusia itu lebih liar dari biasanya. Tuanku jadi dua kali lebih buas. Sang wanita sampai kewalahan dan terkulai. Saat itulah tuanku menyeringai dan mengambilku dari lantai. Ia melilitkan aku di leher sang wanita dengan begitu kuat. Hingga aku bisa merasakan tiap denyut nadi. Sang wanita meronta dan aku berteriak sekuat tenaga. Tapi kami berdua sama-sama tak berdaya. Rontaan sang wanita terlalu lemah. Dan teriakanku tak akan didengar manusia. Air mata wanita itu keluar menahan sakit. Air mataku menetes menahan sakit hati. Tubuhku memang bermotif kelabang merah, tapi aku bukan alat untuk membunuh. Air mata kami terus menetes. Sampai aku tak merasakan lagi gerakan dan denyut di leher wanita itu (Air Mata Seonggok Dasi: 171).
Kutipan di atas menunjukkan kejahatan yang dilakukan oleh sang tuan. Saat sang tuan mengetahui wanitanya mengandung janin hasil perbuatan di luar nikah, sang tuan tidak bertanggung jawab. Sang tuan justru memilih jalan untuk membunuh sang wanita dan calon bayi yang ada di dalam kangdungannya. Pembunuhan ini dilakukan dengan sadis menggunakan dasi sebagai alat untuk membunuh sang wanita yang selama ini mempunyai hubungan di luar nikah bersama sang tuan.

\section{PENUTUP}

\subsection{Kesimpulan}

Berdasarkan hasil dan pembahasan, dapat disimpulkan penelitian mengenai realitas sosial terhadap aspek-aspek masalah sosial yang terdapat pada enam cerpen dalam kumpulan cerpen teriakan dalam bungkam karya Rizqi Turama adalah (1) masalah disorganisasi keluarga terdapat pada cerpen Profesor bermulut runcing dan cerpen Somat memutuskan untuk mati; (2) masalah kejahatan terdapat pada cerpen Pisuh dan makian untuknya dan cerpen air mata seonggok dasi; (3) masalah kemisikinan terdapat pada cerpen Pisuh dan makian untuknya; (4) masalah kependudukan dan masalah generasi muda dalam masyarakat modern terdapat pada cerpen warung bubur di dekat jembatan layang; (5) masalah delinkuensi anak-anak terdapat pada cerpen kobal-kebul televisi Kobel; (6) dan masalah politik terdapat pada cerpen Somat memutuskan untuk mati.

\subsection{Saran}

Adapun saran yang dapat dikemukakan yaitu penelitian ini hanya mengakaji realitas sosial melalui 
masalah sosial yang terdapat pada enam cerpen dalam kumpulan cerpen Teriakan dalam Bungkam karya Rizqi Turama. Hendaknya peneliti lain dapat melakukan penelitian selanjutnya dengan lebih sempurna, baik yang berhubungan dengan penelitian ini, maupun yang berhubungan dengan masalah lain dalam penelitian yang berobjek cerpen Teriakan dalam Bungkam, karna terdapat aspek yang dapat diteliti selain realitas sosial melalui masalah sosial sehingga diperoleh hasil bervariasi dan dapat memperkaya khasanah sastra Indonesia.

\section{DAFTAR PUSTAKA}

Abdullah, Ahmad Abid. 2014. Kritik Sosial Dalam Kumpulan Cerpen Seekor Bebek Yang Mati Di Pinggir Kali Karya Puthut Ea. Https://core.ac.uk/download/pdf/3 3515062.pdf (diakses hari minggu 7 Oktober, pada jam 05: 39).

Endraswara, Suwardi. 2011. Metodologi penelitian Sastra; Epistemologi, Model, Teori, dan Aplikasi. Yogyakarta: Caps.

Faruk. 2016. Pengantar Sosiologi Sastra. Yogyakarta: Pustaka Pelajar.

Jabrohim. 2014. Teori Penelitian Sastra. Yogyakarta: Pustaka Pelajar.

Kosasih, E. 2012. Dasar-dasar Keterampilan Bersastra. Bandung: Penerbit Yrama Widya.

Mei, Titik Yuliana. 2017. Realitas Sosial pada Novel Impian Di Biliki Merah Karya Cao Xueqin. http://jurnalmahasiswa.unesa.ac.id (diakses hari senin 1 april, pada jam 07:30).
Nurgiyantoro, Burhan. 2010. Teori Pengkajian Fiksi. Yogyakarta: Gadjah Mada University Press.

Ratna, Nyoman Kutha. 2013. Paradigma Sosiologi Sastra. Yogyakarta: Pustaka Pelajar.

Ratna, Nyoman Kutha. 2015. Teori, Merode, dan Teknik Penelitian sastra. Yogyakarta: pustaka Pelajar.

Semi, Atar. 1990. Metode Penelitian Sastra bandung: Angkasa.

Soekanto, Soejono.1993. sosiologi suatu Pengantar. Jakarta: PT Raja Grafindo Persada.

Sudarman, Paryati. 2008. Menulis di Media Massa. Yogyakarta: Pustaka Pelajar.

Sugiarto, Eko. 2015. Terampil Menulis; Tips dan Trik Menulis Laporan, Opini, Cerpen, Puisi, Pantun. Yogyakarta: Morfalingua.

Wayuni, Ristri. 2014. Kitab Lengkap puisi, Prosa, dan Pantun Lama. Yogyakarta: Saufa.

Wellek, Rene dan Austin Warren. 2014. Teori Kesusastraan. Jakarta: PT. Gramedia Pustaka Utama. 